\title{
SKRINING ANEMIA SEBAGAI UPAYA PENINGKATAN KESEHATAN IBU HAMIL DI PRAKTIK MANDIRI BIDAN TANJUNG DELITUA
}

\author{
Agnes Purba $^{1}$, Sharfina Haslin ${ }^{2}$ \\ ${ }^{1,2}$ Program Studi Sarjana Kebidanan Universitas Sari Mutiara Indonesia, Medan, Indonesia \\ agnespurba24@yahoo.co.id \\ sharfinahaslin97@gmail.com
}

\begin{abstract}
ABSTRAK
Defisiensi besi merupakan penyebab paling umum anemia pada kehamilan. Komplikasi yang dapat terjadi dari kondisi anemia pada ibu hamil ini adalah perdarahan pasca bersalin, bayi dengan berat badan lahir rendah, kelahiran prematur serta gangguan pertumbuhan dan perkembangan janin. Tablet tambah darah diberikan sekali sehari selama 90 hari selama kehamilan. Survei awal di Praktik Mandiri Bidan (PMB) Tanjung Deli Tua bahwa setiap kunjungan ibu hamil diberikan asuhan antenatal, edukasi tentang kondisi kesehatan ibu dan janin serta pemberian tablet zat besi, namun pemantauan kondisi kesehatan ibu melalui pengecekan Hemoglobin tetap harus dilakukan untuk memastikan efektifitas tablet zat besi yang diberikan pada ibu hamil. Untuk itu dilakukan PkM ini sebagai skrining anemia pada kehamilan. Pengabdian kepada masyarakat ini dilaksanakan di PMB Tanjung Deli Tua dengan bentuk kegiatan yaitu pemeriksaan ibu hamil, pemeriksaan kadar hemoglobin dengan alat easy touch, pemberiaan tablet zat bezi dan pemberian edukasi tentang manfaat dan cara konsumsi tablet zat besi yang benar. Diperoleh hasil mayoritas Lingkar Lengan Atas (LiLA) ibu hamil adalah adalah $\geq 23,5 \mathrm{~cm}$ $(95,4 \%)$ dan mayoritas ibu hamil dengan sekundigravida (52,2\%). Kemudian ditemukan dari 46 orang ibu hamil yang diperiksa 1 orang (2\%) mengalami anemia. Melalui kegiatan PkM ini perlu adanya kerjasama dengan puskesmas terdekat untuk pemberian makanan tambahan bagi ibu hamil yang mengalami anemia dan KEK.
\end{abstract}

Kata Kunci : Skrining Anemia, Ibu Hamil, Pemeriksaan Hemoglobin

\begin{abstract}
Iron deficiency is the most common cause of anemia in pregnancy. Complications that can occur from anemia in pregnant women are postpartum hemorrhage, low birth weight babies, premature birth and impaired fetal growth and development. Iron tablets are given once a day for 90 days during pregnancy. The survey at the Tanjung Clinic District Deli Tua that every pregnant woman is given antenatal care, education about the health condition of the mother and fetus and the administration of iron tablets, however monitoring of maternal health conditions through checking hemoglobin must still be carried out to ensure the effectiveness of iron tablets given to pregnant women. For this reason, PkM is carried out as a screening for anemia in pregnancy. This community service was carried out at PMB Tanjung Deli Tua in the form of physical examinations for pregnant women, checking hemoglobin levels with an easy touch device, giving iron tablets and providing education about the benefits and how to consume iron tablets correctly. The results obtained were that the majority of LiLA of pregnant women were 23.5 $\mathrm{cm}(95.4 \%)$ and the majority of pregnant women were secondary (52.2\%). Then it was found out of 46 pregnant women who were examined 1 person (2\%) had anemia. Through this PkM activity, it is necessary to collaborate with the nearest puskesmas to provide additional food for pregnant women who experience anemia and KEK.
\end{abstract}

Keywords: Anemia Screening, Pregnant Women, Hemoglobin Examination 


\section{PENDAHULUAN}

Angka kejadian anemia pada ibu hamil di Indonesia mencapai 40,2\% dari seluruh kehamilan (Natalia, Sumarmi, \& Nadhiroh, 2015) dan belum mampu mencapai target nasional karena berbagai kendala (Kemenkes, 2016). Hasil Riset Kesehatan Dasar Kementerian Kesehatan Republik Indonesia (Riskesdas Kemenkes RI) melaporkan bahwa pada tahun 2014 cakupan tablet tambah darah ibu hamil di Indonesia sebesar 85,1\% dan tidak mengalami peningkatan dibandingkan tahun 2015 sebesar 85,17\%, bahkan mengalami penurunan pada tahun 2017 sebesar 73,2\% (Kemenkes, 2018). Faktor penyebab yang anemia pada ibu hamil adalah defisiensi zat besi. Defisiensi besi pada ibu hamil terjadi karena : 1) kurangnya asupan zat besi dalam makanan sehari yang dikonsumsi oleh ibu; 2) makanan yang dikonsumsi oleh ibu mengandung zat penghambat besi untuk diabsorbsi oleh tubuh; 3) dukungan terhadap ibu hamil masih kurang dalam keluarga sehingga distribusi makanan yang bergizi tidak utama bagi ibu; 4) keadaan ekonomi keluarga pada level rendah; 5) masih kurangnya informasi tentang anemia dan pencegahannya (Parulian \& Roosleyn, 2016).

Pemerintah membuat kebijakan bahwa setiap ibu hamil wajib mengkonsumsi tablet zat besi yang diberikan oleh petugas kesehatan sebanyak 90 tablet, namun hal tersebut tidak juga dapat menurunkan angka kejadian anemia pada ibu hamil (Kemenkes, 2016). Zat besi merupakan mineral yang dibutuhkan untuk proses pembentukan sel darah merah (hemoglobin). Pemberian tablet tambah darah merupakan salah satu upaya yang efektif dalam penanggulangan anemia dalam kehamilan akibat kekurangan besi dan atau asam folat. Tablet tambah darah diberikan sekali sehari selama minimal 90 hari selama kehamilan. Adapun komposisi tablet tambah darah untuk ibu hamil adalah mengandung $60 \mathrm{mg}$ besi elemental dalam bentuk sediaan ferro sulfat, ferro fumarate atau ferro gluconate dan asam folat $0,4 \mathrm{mg}$ (PMK RI, 2014).

Pengamatan dilokasi Pengabdian kepada Masyarakat (PkM) yaitu di Praktik Mandiri Bidan (PMB) Klinik Tanjung Deli Tua bahwa rata-rata kunjungan pemeriksaan ibu hamil sebanyak 80-100 ibu hamil setiap bulannya. Asuhan antenatal ini bertujuan untuk mencapai kehamilan yang sehat artinya tercapai peningkatan kesehatan ibu dan bayi baru lahir. Pencapaian kesehatan ibu dan bayi yang optomal tidak terlepas dari pemantauan atau skrining terhadap keadaan ibu. Skrining tersebut dapat dilakukan dengan pemeriksaan hemoglobin ibu hamil. Memang setiap ibu hamil yang melakukan pemeriksaan di Klinik Tanjung Deli Tua diberikan tablet zat besi serta diberikan juga edukasi cara konsumsi yang baik dan benar. Namun tetap harus dilakukan pemantauan terhadap kadar hemoglobin untuk memastikan ibu hamil tidak mengalami anemia.

Berdasarkan latar belakang tersebut diatas, maka tim melakukan Pengabdian kepada Masyarakat (PkM) yang bertujuan untuk meningkatkan kesehatan ibu hamil melalui skrining anemia sebagai upaya deteksi dini, pencegahan dan penanganan anemia pada ibu hamil yang dilakukan di PMB Tanjung Deli Tua. 


\section{METODE}

Pelaksanaan kegiatan PkM ini yaitu dalam bentuk pemeriksaan ibu hamil, pemeriksaan kadar hemoglobin, pemberiaan tablet zat bezi dan pemberian edukasi tentang manfaat dan cara konsumsi tablet zat besi yang benar. Sebelum dilakukan pemeriksaan hemoglobin, terlebih dahulu dilakukan pemeriksaan fisik pada ibu hamil, selanjutnya pengecekan hemoglobin ibu menggunakan alat easy touch. Setelah selesai maka ibu hamil diberitahukan hasil pemeriksaan dan diakhir dengan pemberian penyuluhan tentang anemia serta manfaat tablet zat besi.

Lokasi kegiatan PkM di Praktik Mandiri Bidan (PMB) Tanjung Deli Tua yang dimulai dari minggu pertama sampai minggu ketiga Desember 2021. Peserta kegiatan PkM skrining anemia ini adalah ibu hamil trimester III yang berkunjung melakukan pemeriksaan kehamilan pada minggu pertama sampai minggu ketiga Desember 2021 dengan jumlah seluruhnya 46 orang.

\section{HASIL DAN PEMBAHASAN}

\section{Hasil}

Pelaksanaan pengabdian masyarakat dengan topik "Skrining Anemia Pada Ibu Hamil Melalui Pemeriksaan Hemoglobin" telah terlaksana dan berjalan dengan baik. Sebanyak 46 orang ibu hamil mengikuti kegiatan dengan antusias. Ibu hamil yang menjadi peserta $\mathrm{PkM}$ dengan karakteristik dijelaskan pada tabel sebagai berikut :

Tabel 1. Karakteristik Ibu Hamil

\begin{tabular}{clcc}
\hline No & Karakteristik Ibu Hamil & Frekuensi & Persentasi \\
\hline 1 & LiLA $<23,5 \mathrm{~cm}$ & 1 & 2,0 \\
& LiLA $\geq 23,5 \mathrm{~cm}$ & 45 & 98,0 \\
\hline \multicolumn{1}{c}{ Jumlah } & 46 & 100 \\
\hline 2 & Primigravida & 12 & 26,1 \\
& Sekundigravida & 24 & 52,2 \\
& Multrigravida & 10 & 21,7 \\
\hline \multicolumn{2}{c}{ Jumlah } & 46 & 100 \\
\hline 3 & Anemia $(\mathrm{Hb}>11$ gr/dL) & 1 & 2,0 \\
& Tidak Anemia $(\geq 11$ & 45 & 98,0 \\
& gr/dL) & & 100 \\
\hline & Jumlah & 46 & \\
\hline
\end{tabular}

Hasil pendataan diperoleh bahwa mayoritas Lingkar Lengan Atas (LiLA) ibu hamil adalah adalah $\geq 23,5 \mathrm{~cm}(95,4 \%)$ dan mayoritas ibu hamil dengan sekundigavida $(52,2 \%)$. Kemudian ditemukan dari 46 orang ibu hamil yang diperiksaan terdapat 1 orang (2\%) yang mengalami anemia. 


\section{Pembahasan}

Standar pelayanan kesehatan ibu hamil yang dilakukan di PMB Tanjung Deli Tua meliputi : anamnesa, pemeriksaan fisik, pemeriksaan palpasi abdominal, pemeriksaan laboratorium (jika diperlukan), pendidikan kesehatan serta pemberian tablet zat besi. Pemberian tablet tambah darah diberikan pada ibu hamil secara gratis. Sedangkan, pemeriksaan kadar hemoglobin dilakukan pada trimester 1 dan 3 kehamilan.

Sedangkan prosedur untuk menegakkan diagnosis anemia pada ibu hamil yang kunjungan kehamilan di PMB Tanjung yaitu:

a) Anamnesa

Untuk menegakkan diagnosis anemia kehamilan dapat dilakukan dengan anamnesa. Pada anamnesa akan didapatkan keluhan cepat lelah, sering pusing, mata berkunang-kunang, nafsu makan berkurang, keluhan hamil bertambah.

b) Pemeriksaan fisik

Dijumpai adanya tanda tanda anemia yaitu diantaranya pucat, ikterus, hipotensi dan bantalan kuku pucat, takipnea dan dyspnea saat beraktifitas.

c) Pemeriksaan laboratorium

Pemeriksaan darah dilakukan minimal dua kali selama kehamilan, yaitu pada trimester I dan trimester III dengan pertimbangan bahwa sebagian besar ibu hamil mengalami anemia pada trimester tersebut, maka dilakukan pemberian preparat tambah darah sebanyak 90 tablet pada ibu hamil di puskesmas. Pemeriksaan dan pengawasan hemoglobin dilakukan menggunakan alat easy touch.

Hasil pengkajian dari 46 orang ibu hamil yang diperiksa, terdapat 1 orang (2\%) dengan LiLA dibawah $23,5 \mathrm{~cm}$. Lingkar lengan atas adalah gambaran tentang keadaan jaringan otot dan lapisan lemak bawah kulit. Pengukuran LiLA dilakukan pada pertengahan antara panggkal lengan atas dan ujung siku dalam ukuran senti meter $(\mathrm{cm})$ (Wahyuni dan Huda, 2018). Lingkar lengan atas merupakan salah satu indikator status gizi ibu hamil. Jika kurang dari 23,5 cm maka ibu hamil termasuk Kurang Energi Kronis (KEK) yang dapat menimbulkan risiko melairkan bayi dengan berat lahir rendah (Kemenkes, 2016).

Kehamilan menyebabkan meningkatnya kebutuhan energi dan gizi lainnya. Peningkatan energi dan zat gizi ini diperlukan untuk pertumbuhan dan perkembangan janin, penambahan besarnya organ kandungan, perubahan komposisi dan metablisme tubuh ibu sehingga kekurangan gizi tertentu yang dibutuhkan saat hamil dapat menyebabkan pertumbuhan janin terganggu (Putri dan Muqsith, 2015). Oleh sebab itu ibu hamil harus memenuhi asupan zat gizinya dengan mengkonsumsi makanan yang mengandung karbohidrat, mineral, protein, vitamin dan lemak. 

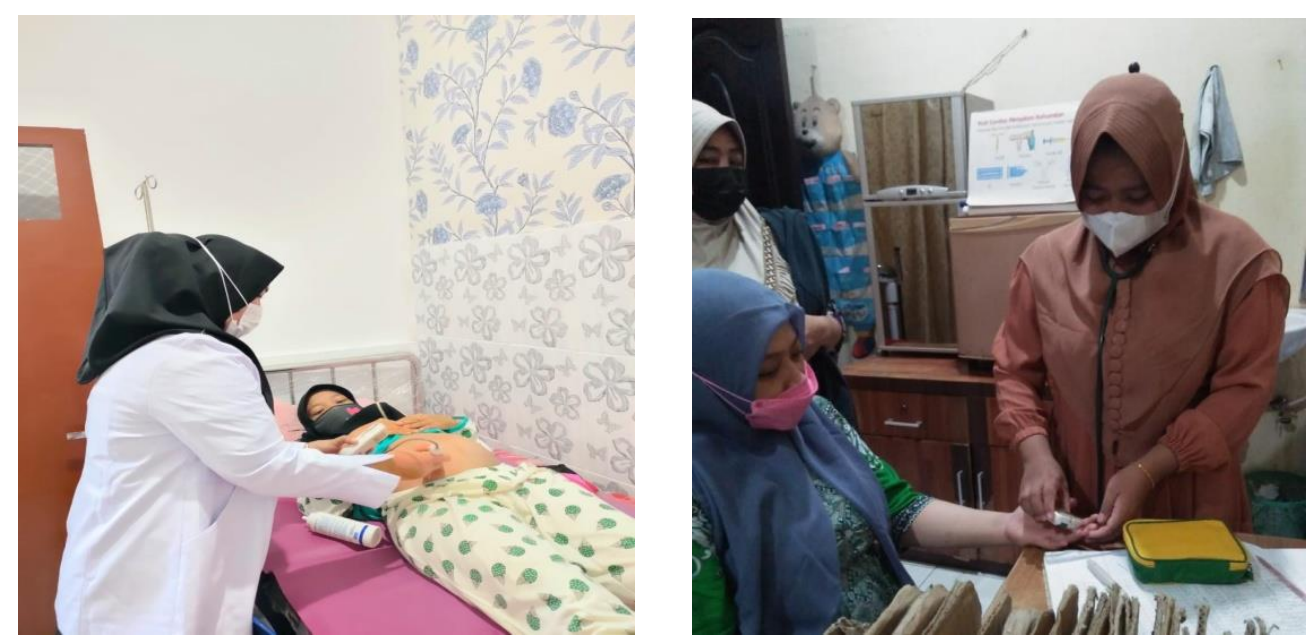

Gambar 1. Pemeriksaan Fisik dan Hemoglobin Ibu Hamil

Hasil pemeriksaan hemoglobin ibu hamil pada PkM ini juga ditemukan bahwa 1 orang (2\%) ibu hamil mengalami anemia. Ibu hamil yang mengalami anemia ini juga yang mengalami KEK (LiLA < 23,5 cm). Artinya kekurangan energi kronik pada ibu hamil disebabkan karena kurangnya asupan energi dan zat gizi yang berlangsung lama sehingga menimbulkan gangguan kesehatan, salah satunya adalah menyebabkan anemia pada kehamilan.

Responden pada PkM ini adalah ibu hamil trimester III, justru kebutuhan akan zat gizi pada trimester ini meningkat karena janin menyimpan zat besi untuk persediaan dirinya dibulan pertama kelahiran (Setyawati dan Syauqy, 2014) sehingga konsumsi tablet zat besi pada trimester III harus secara rutin supaya kebutuhan janin tercukupi. Hasil observasi pada PkM ini ibu hamil telah diberikan tablet zat besi sebanyak 90 tablet dengan dosis $60 \mathrm{mg}$ perhari yang harus dikonsumsi

Selain pemberian tablet zat besi, pendidikan kesehatan tentang gizi bagi ibu hamil dan pentingnya mengkonsumsi tablet zat besi telah diberikan pada kelompok ibu hamil selama PkM ini. Setiap ibu hamil yang kunjungan, disesi akhir diberikan penjelasan tentang jenis zat gizi yang harus dikonsumsi ibu hamil, manfaat zat gizi tersebut bagi pertumbuhan dan perkembangan janin serta manfaat dan cara mengkonsumsi tablet zat besi yang diberikan. Jenis asupan gizi sederhana yang dapat dikonsumsi ibu antara lain sayur, buah, telur, dll. Pendidikan kesehatan ini dilakukan untuk memberikan pengetahuanpada ibu hamil agar ibu terhindar dari komplikasi anemia dan sebagai pencegahan terhadap anemia. 


\section{KESIMPULAN}

Kegiatan PkM yang dilaksanakan ini diikuti sebanyak 46 orang ibu hamil yang diperiksa dan diberikan edukasi saat kunjungan di PMB Tanjung Deli Tua. Terdapat 1 orang ibu hamil yang mengalami Kurang Energi Kronik (KEK) dan juga mengalami anemia. Setelah mengikuti kegiatan PkM ini, ibu hamil yang menjadi responden sangat antuasias serta telah memahami tentang manfaat asupan gizi dan konsumsi tablet zat besi bagi ibu dan pertumbuhan janin serta untuk mencegah komplikasi dari KEK dan anemia ibu hamil bersedia untuk mengkonsumsi sayur, buah, lauk dan tablet zat besi.

\section{UCAPAN TERIMA KASIH}

Pada kesempatan ini penulis mengucapkan terima kasih kepada Pimpinan dan Ketua LPPM Universitas Sari Mutiara Indonesia yang telah memberikan dukungan dan ijin sehingga kegiatan PkM ini terlaksana dengan baik. Ucapan terima kasih yang sebesar-besarnya juga penulis ucapkan kepada Pimpinan Klinik Tanjung Deli Tua atas kerjasamanya selama kegiatan PkM berlangsung.

\section{REFERENSI}

Aryani, F. (2017). Hubungan Anemia Pada Saat Kehamilan Dengan Kejadian Perdarahan Postpartum Di RSUD Panembahan Senopati Bantul Tahun 2017.

Imdad, A., \& Bhutta, Z. A. (2012). Routine iron/folate supplementation during pregnancy: Effect on maternal anaemia and birth outcomes. Paediatric and Perinatal Epidemiology, 26 (SUPPL. 1), 168-177. https://doi.org/10.1111/j.1365$\underline{\text { 3016.2012.01312.x }}$

Kemenkes, R. (2016). Profil Kesehatan Indonesia Tahun 2016.

Kemenkes, R. (2018). Riset Kesehatan Dasar Tahun 2018.

Parulian, I., \& Roosleyn, T. (2016). Strategi Dalam Penanggulangan Pencegahan Anemia Pada Kehamilan. Jurnal Ilmiah Widya, 3.

Putri, A.R., Muqsith, A. (2015). Hubungan Lingkar Lengan Atas Ibu Hamil Dengan Berat Badan Lahir Bayi Di Rumah Sakit Umum Cut Meutia Kabupaten Aceh Utara Dan Rumah Sakit Tingkat IV Lhokseumawe. Jurnal Kedokteran dan Kesehatan Malikussaleh.

Setyawati, B., \& Syauqy, A. (2014). Perbedaan Asupan Protein, Zat Besi, Asam Folat, Dan Vitamin B12 Antara Ibu Hamil Trimester III Anemia Dan Tidak Anemia Di Puskesmas

Tanggungharjo Kabupaten Grobogan. Journal of Nutrition College.

Wahyuni, Y., Huda, A.S.M. (2019). Pemantauan Kesehatan Gizi Ibu Hamil Dilihat dari Pertambahan Berat Badan dan Pengukuran Lingkar Lengan Atas (LILA) Berbasis E-Digital. Jurnal Ilmiah Ilmu Komputer dan Matematika, 16; (1), 235-244.

Young, M. F. (2018). Maternal anaemia and risk of mortality: a call for action. The Lancet Global Health, 6(5), e479-e480. https://doi.org/10.1016/S2214-109X (18) 30185-2. 